\title{
ANALISIS KUALITATIF DAN KUANTITATIF BORAKS PADA CINCAU HITAM YANG BEREDAR DI TANGERANG SELATAN DENGAN METODE ASIDIMETRI
}

\author{
Beny Maulana Satria, Nur Hasanah, Nurul Istiqomah \\ Sekolah Tinggi Ilmu Kesehatan Kharisma Persada \\ Tangerang Selatan, 15417, Indonesia \\ E-mail: benymaulana1@gmail.com
}

\begin{abstract}
ABSTRAK
Di negara Indonesia boraks sudah digunakan sebagai bahan pengawet makanan. Dari hasil pengujian sampel di laboratorium Badan Pengawasan Obat dan Makanan (BPOM) yang dilakukan pada tahun 2011 mencakup wilayah Bandar Lampung, Jakarta, Bandung, Semarang, Yogyakarta, Surabaya, Mataram, dan Makassar telah dilakukan pengambilan sampel dan pengujian laboratorium sejumlah 20,511 sampel pangan. Tujuan dari penelitian ini adalah untuk mengetahui ada tidaknya kandungan boraks dalam cincau hitam yang beredar di Tangerang Selatan. Penelitian ini menggunakan metode titrasi asidimetri dengan proses pengambilan secara acak 10 sampel cincau hitam dari pedagang kaki lima, pasar dan supermarket yang beredar di Tangerang Selatan. Hasil penelitian boraks pada cincau hitam yang beredar di Tangerang Selatan untuk uji pembusukan terdapat 6 sampel yang mengandung bahan pengawet dan bahan tambahan lainnya, pada uji nyala terdapat 4 sampel yang mengandung boraks dan menunjukkan warna nyala api hijau,biru dan biru kehijauan, pada titrasi asidimetri terdapat 10 sampel mengandung boraks. Dari hasil penelitian diketahui terdapat kandungan boraks dan bahan tambahan pada Cincau hitam yang beredar di Tangerang Selatan. Kadar boraks terendah pada cincau hitam sebanyak 22,3 gram $/ \mathrm{kg}$ dan yang tertinggi yaitu $33,6 \mathrm{gram} / \mathrm{kg}$.
\end{abstract}

Kata kunci : Cincau hitam, boraks, titrasi, asidimetri, uji nyala api

\begin{abstract}
In the state of indonesia borax had been used here as an ingredient of a food preservative. From the results of testing the sample at lab where internal conditions food and drug monitoring agency ( from food and medicine supervision) who conducted in a number of 2011 included the sites of Bandar Lampung , Jakarta, garbage generated by Bandung residents, Semarang the capital city of, Yogyakarta in central java, Surabaya, Mataram, and Makassar to be channeled has been carried out the sample collection and examination on lab where internal conditions a number of sample 20,511 food was laid aside as.The whole purpose of the of this research is to know if there are the moisture content of borax in black jellyfish which circulates in south tangerang. Was used in the study a method of titration acidimetry with the process of over the withdrawal of funds at random sample 10 black jellyfish from street vendors, the market and supermarkets which circulates in South Tangerang. The results of the study borax in black cincau circulating in south tangerang decay 6 is to test samples containing preservative, other additional and materials in the flame is 4 sample containing borax and showed the fiery, green color blue and blue, greenish in titrations acidimetry 10 containing borax. sample isThe research is known the borax and extra ingredient in black cincau circulating in south tangerang.The lowest in the borax cincau black 22,3 / grams as the highest $\mathrm{kg}$ and kg 33,6 / grams.
\end{abstract}

Keywords : Black jellyfish, borax titration, acidimetry, the flame 


\section{PENDAHULUAN}

Penelitian ini dilakukan untuk mengetahui ada tidaknya kandungan boraks dalam cincau hitam yang beredar di Tangerang Selatan. Saat ini banyak makanan yang ditambahkan boraks karena untuk pengawet dan pengenyal makanan. Menurut Badan Pengawasan Obat dan Makanan (BPOM) yang dilakukan pada tahun 2011 mencakup wilayah Bandar Lampung, Jakarta, Bandung, Semarang, Yogyakarta, Surabaya, Mataram, dan Makassar telah dilakukan pengambilan sampel dan pengujian laboratorium sejumlah 20,511 sampel pangan mengandung boraks dan formalin.

Cincau merupakan gel berupa agaragar yang diperoleh perendaman daun (atau organ lain) tumbuhan tertentu dalam air. Secara umum terdapat dua jenis cincau, yaitu cincau hijau yang terdiri dari cincau hijau pohon (Premna oblongifolia Merr) maupun cincau hijau rambat (Cyclea barbata L Mier) dan cincau hitam (Mesona Palustris B). Hasil penilitian Mardiah, dkk (2007) menunjukan bahwa ekstrak air cincau dapat menurunkan sel kanker. Beberapa komponen berperan aktif dalam cincau adalah karotenoid, flavonoid, dan klorofil. Senyawa-senyawa tersebut bersifat antioksidan, adapun komponen-komponen lain yang terkandung dalam cincau adalah protein, lemak, besi, kalsium, fosfor, vitamin A, vitamin B1, vitamin $\mathrm{C}$, dan lain-lain (Astawan, 2004).

Pengolahan cincau dapat dilakukan dengan beberapa cara, antara lain dengan proses tanpa pemanasan seperti pada pengolahan daun cincau hijau, dan dengan bantuan pemanasan yang dilakukan pada pengolahan cincau hitam. Cincau hitam banyak digunakan di masyarakat karena mengandung banyak zat aktif yang bermanfaat seperti antioksidan, cincau ini juga banyak digunakan sebagai campuran minuman yang diminati oleh konsumen. Akan tetapi pengolahan cincau hitam yang menggunakan proses pemanasan, tentunya dapat berpengaruh pada kualitas gizi terutama antioksidan yang terkandung daun cincau tersebut (Vanoria dan Farida 2008).

Cincau hitam dapat digunakan sebagai penurun panas dalam, sakit perut, diare, batuk, sariawan, dan penurun tekanan darah tinggi.Beberapa komponen aktif cincau yang memiliki nilai fungsional diantaranya baik dari golongan polifenol, saponin, flavonoid maupun alkaloid.Cincau juga mempunyai aktivitas 
antioksidan yang mampu mematikan sel tumor dan kanker.

\section{METODE}

Instrument penelitian yang digunakan adalah pemeriksaan/uji laboratorium dengan metode uji pembusukkan, uji nyala dan titrasi asidimetri.Rancangan penelitian yang digunakan adalah jenis penelitian deskriptif di laboratorium yaitu mendeteksi kandungan boraks pada cincau hitam yang beredar di Tangerang Selatan. Cara pengambilan sampel dalam penelitian ini menggunakan teknik probability sampling yaitu pengambilan sampel secara random atau acak.

\section{HASIL}

Tabel 1. Uji pembusukkan pada cincau hitam

\begin{tabular}{|c|c|c|}
\hline No & Asal sampel & Hasil \\
\hline 1 & Pasar Ciputat & Positif \\
\hline 2 & Pasar Serpong & Positif \\
\hline 3 & $\begin{array}{l}\text { Pedagang kaki lima } \\
\text { Pamulang asal } \\
\text { cincau ritam } \\
\text { carefour Pamulang }\end{array}$ & Positif \\
\hline 4 & $\begin{array}{l}\text { Pedagang kaki lima } \\
\text { Ciputat asal cincau } \\
\text { hitam Ciputat }\end{array}$ & Negatif \\
\hline 5 & Giant Pamulang & Negatif \\
\hline 6 & $\begin{array}{l}\text { Pedagang kaki lima } \\
\text { Serpong asal cincau } \\
\text { hitam pasar } \\
\text { Serpong }\end{array}$ & Positif \\
\hline 7 & $\begin{array}{l}\text { Pedagang kaki lima } \\
\text { Reni asal cincau } \\
\text { hitam pasar Reni }\end{array}$ & Negatif \\
\hline 8 & Pasar Pamulang & Negatif \\
\hline
\end{tabular}

\begin{tabular}{lll}
\hline No & Asal sampel & Hasil \\
\hline 9 & Superindo Ciputat & Positif \\
\hline 10 & Giant Ciputat & Positif \\
\hline
\end{tabular}

Tabel 2. Uji nyala pada cincau hitam

\begin{tabular}{|c|c|c|}
\hline No & Asal sampel & Hasil \\
\hline 1 & Pasar Ciputat & Positif \\
\hline 2 & Pasar Serpong & Negatif \\
\hline 3 & $\begin{array}{lr}\text { Pedagang kaki lima } \\
\text { Pamulang asal } \\
\text { cincau } & \text { hitam } \\
\text { carefour Pamulang }\end{array}$ & Negatif \\
\hline 4 & $\begin{array}{l}\text { Pedagang kaki lima } \\
\text { Ciputat asal cincau } \\
\text { hitam Ciputat }\end{array}$ & Negatif \\
\hline 5 & Giant Pamulang & Negatif \\
\hline 6 & $\begin{array}{l}\text { Pedagang kaki lima } \\
\text { Serpong asal cincau } \\
\text { hitam pasar } \\
\text { Serpong }\end{array}$ & Positif \\
\hline 7 & $\begin{array}{l}\text { Pedagang kaki lima } \\
\text { Reni asal cincau } \\
\text { hitam pasar Reni }\end{array}$ & Negatif \\
\hline 8 & Pasar Pamulang & Positif \\
\hline 9 & Superindo Ciputat & Positif \\
\hline 10 & Giant Ciputat & Negatif \\
\hline
\end{tabular}

Tabel 3. Titrasi asidimetri

\begin{tabular}{lll}
\hline No & Asal sampel & Hasil \\
\hline 1 & Pasar Ciputat & Positif \\
\hline 2 & Pasar Serpong & Positif \\
\hline 3 & $\begin{array}{l}\text { Pedagang kaki lima } \\
\text { Pamulang Positif } \\
\text { cincau hal hitam } \\
\text { carefour Pamulang }\end{array}$ \\
\hline 4 & $\begin{array}{l}\text { Pedagang kaki lima } \\
\text { Ciputat asal cincau } \\
\text { hitam Ciputat }\end{array}$ \\
\hline 5 & Piant Pamulang & \\
\hline 6 & $\begin{array}{l}\text { Pedagang kaki lima } \\
\text { Serpong asal cincau }\end{array}$ & Positif \\
& hitam pasar Serpong \\
\hline 7 & $\begin{array}{l}\text { Pedagang kaki lima } \\
\text { Reni asal cincau } \\
\text { hitam pasar Reni }\end{array}$ \\
\hline 8 & Pasar Pamulang & Positif \\
\hline 9 & Superindo Ciputat & Positif \\
\hline
\end{tabular}




\begin{tabular}{lll}
\hline No & Asal sampel & Hasil \\
\hline 10 & Giant Ciputat & Positif \\
\hline
\end{tabular}

\section{DISKUSI}

Analisis kualitatif boraks pada cincau hitam dilakukan dengan metode uji pembusukan karena untuk mengetahui ada tidaknya boraks pada suhu ruangan. Cincau hitam yang tanpa pengawet berbahaya akan bertahan selama 2 hari pada suhu ruangan ataupun dalam freezer. Cincau hitam yang berasal dari pasar Ciputat, pasar Serpong, pedagang kaki lima Pamulang, pedagang kaki lima Serpong, Superindo Ciputat, giant Ciputat menunjukan hasil yang positif bahan pengawet dan bahan tambahan lainnya karena tekstur nya kenyal dan tidak mudah hancur, seharusnya gel cincau hitam yang baik sedikit kenyal, mudah hancur saat ditekan/digerus dan warna tidak menempel ke tangan saat dipegang.

Selain itu, aroma gel cincau hitam yang baik seperti aroma daun cincau hitam saat direbus, aroma tidak menyengat tetapi sampel yang didapatkan beraroma lumpur tanah dan aroma menyengat daun cincau hitam dan bahan tambahan lainnya. Cincau hitam pada hari kedua dan ketiga seharusnya timbul jamur dan belatung karena suhu ruangan di dalam rumah berubah - ubah tergantung cuaca dan dihinggapi binatang kecil seperti semut karena pada saat proses pembuatannya ditambahkan sedikit gula agar terasa manis tetapi sampel yang didapatkan masih terlihat segar seperti pertama dibeli, tidak dihinggapi binatang kecil, hanya ada beberapa jamur dan belatung.

Cincau hitam yang berasal dari pedagang kaki lima Ciputat, giant Pamulang, pedagang kaki lima Reni dan pasar Pamulang menunjukkan hasil yang negatif karena bau, warna dan tekstur sesuai dengan literatur. Sampel pada hari kedua dan ketiga timbul/muncul jamur dan belatung walaupun hanya beberapa yang timbul. Sampel yang didapatkan sebanyak 10 sampel cincau hitam yang beredar di Tangerang Selatan, dari 10 sampel tersebut ada 6 sampel yang positif mengandung bahan pengawet dan bahan tambahan lainnya sedangkan 4 sampel menunjukkan hasil negatif. Hasil tersebut belum pasti mengandung boraks karena penelitian ini dilihat dari organoleptis.

Pada uji nyala api, metode ini dilakukan bertujuan untuk mengetahui ada/tidak ada boraks dalam cincau hitam yang ditandai warna nyala api hijau,biru dan biru kehijauan. Setelah dilakukan uji pembusukkan maka selanjutnya dilakukan uji nyala karna hasil dari uji pembusukkan belum pasti. Cincau hitam yang berasal 
dari pasar Ciputat, pedagang kaki lima Serpong, pasar Pamulang dan superindo Ciputat menunjukkan hasil positif boraks dengan ditandai warna nyala api hijau, biru dan biru kehijauan.

Cincau hitam yang telah dilakukan preparasi kemudian dimasukkan kedalam cawan porselen kemudian ditambah dengan asam sulfat pekat akan dihasilkan asam ortoborat $\left(\mathrm{H}_{3} \mathrm{BO}_{3}\right)$ dan apabila mengandung boron trioksida $\left(\mathrm{B}_{2} \mathrm{O}_{3}\right)$, asam ortoborat yang terbentuk akan bereaksi dengan etanol membentuk ester etil borat $\left[\mathrm{B}\left(\mathrm{OC}_{2} \mathrm{H}_{5}\right)_{3}\right]$ yang bersifat mudah menguap sehingga menunjukkan warna nyala api hijau (Eulalia, 2007).

Hasil penelitian cincau hitam yang berasal dari pasar Serpong, pedagang kaki lima Pamulang, pedagang kaki lima Ciputat, giant Pamulang, pedagang kaki lima Reni dan giant Ciputat menggunakan uji nyala menunjukkan tidak mengandung boraks yang ditandai dengan warna nyala merah dan warna nyala api oren. Sampel yang tidak terdeteksi warna nyala hijau dikarenakan oleh beberapa faktor seperti adanya senyawa pengganggu dari sampel cincau hitam. Hal ini dikarenakan dalam proses penyerbukan sampel tidak melalui proses penghilangan komponen atau senyawa pengganggu.
Penelitian Roth di dalam Tubagus et.al (2013) mengatakan bahwa sampel yang akan dilakukan uji nyala api harus dimasukkan dalam tanur dengan suhu 800oC sampai terbentuk abu. Silalahi (2010) menjelaskan tujuan pengabuan adalah untuk mendestruksi seluruh senyawa asam boraks serta menghilangkan ion-ion yang akan mengganggu pada saat dilakukan identifikasi nyala. Proses preparasi sampel uji nyala dalam penelitian ini dilakukan dengan cara menguapkan kandungan air bebas $\mathrm{CO} 2$ yang terdapat pada sampel diatas penangas air sampai seluruh air pada sampel menguap sempurna.

Pada analisis kuantitatif boraks pada cincau hitam dilakukan dengan metode titrasi asidimetri.Penggunaan $\mathrm{HCl}$ pada saat titrasi karena $\mathrm{HCl}$ membentuk garam yang mudah larut dalam air.Larutan standar yang diinginkan biasanya dibuat dengan mengencerkan asam yang pekat. Tetapi dalam pengenceran sering diperoleh konsentrasi yang tidak tepat, hanya mendekati saja, oleh sebab itu perlu distandarisasikan. Dilakukan pengenceran 1x untuk mendapatkan larutan standar HCl murni (Underwood,1996).

Cincau hitam saat melakukan titrasi ditambahkan indikator metil merah karena indikator metil merah merupakan salah 
satu indikator dalam titrasi asidimetri, yang akan menunjukkan perubahan warna pada rentang $\mathrm{pH}$ yang agak asam (4,5-6), sehingga cocok digunakan untuk sampel dengan $\mathrm{pH}>4,5$. Hasil penelitian boraks pada cincau hitam yang beredar di Tangerang Selatan terdapat 10 sampel mengandung boraks yang menunjukan warna merah kehitaman karena pada saat titrasi berubah warna dari kuning menjadi merah tetapi tidak melebihi batas aman boraks. Batas aman boraks didalam tubuh adalah $1000 \mathrm{mg} / \mathrm{kg}$.

Menurut Saparinto dan Hidayat (2006) dosis tertinggi boraks yaitu 10 gram/kg - 20 gram/kg orang dewasa dan 5 gram $/ \mathrm{kg}$ anak-anak. Berdasarkan data tersebut dibandingkan dengan data penelitian yaitu kadar tertinggi boraks sebanyak 33,6 gram/kg dan kadar terendah sebanyak 22,3 gram $/ \mathrm{kg}$. Kadar boraks cincau hitam yang beredar di Tangerang Selatan melebihi dosis orang dewasa dan anak-anak tetapi tidak melebihi batas aman boraks didalam tubuh manusia. Hasil titrasi menunjukkan hasil yang berbeda - beda, semakin besar kadar boraks maka semakin banyak titran yang dibutuhkan.

\section{SIMPULAN}

Hasil penelitian menunjukkan bahwa cincau hitam banyak digunakan untuk minuman herbal karena memiliki manfaat seperti penurun panas dalam, sakit perut, diare, batuk, sariawan dan penurun tekanan darah tinggi.Penelitian ini dilakukan untuk mengetahui ada/tidak ada boraks dengan metode uji pembusukkan, uji nyala dan mengetahui kadar boraks dengan metode titrasi asidimetri. Hasil uji pembusukkan dari 10 sampel didapatkan 6 sampel yang mengandung bahan tambahan dan bahan pengawet lainnya, uji nyala dari 10 sampel didapatkan 4 sampel yang berwarna nyala api hijau, biru dan biru kehijauan yaitu cincau hitam yang berasal dari pedagang kaki lima Serpong dan giant Lebak bulus dan titrasi asidimetri dari 10 sampel didapatkan 10 sampel yang berwarna merah. Kadar boraks pada saat titrasi tidak melebihi batas aman boraks didalam tubuh manusia.Boraks merupakan zat pengawet berbahaya yang tidak diijinkan sebagai campuran bahan makanan.

\section{DAFTAR PUSTAKA}

Ananta, Aris. 2000. Ekonomi Sumber Daya Manusia, Jakarta :

LPFE.

Anonim.(2003). Laporan Parktikum Penentuan Kadar Air. 
Astawan, M. 2004. Tetap Sehat dengan Produk Makanan Olahan Tiga Serangkai Solo.

Athaya, R.Z., 2015. Identifikasi Boraks Pada Cincau Hitam yang diproduksi beberapa produsen cincau hitam di Kota Padang. Jurnal Kesehatan, Fakultas Kedokteran Universitas Andalas, Padang.

Daintith, J., 1997, Kamus Lengkap Kimia, Erlangga, Jakarta, pp. 7, 17, 84, 87.

Gandjar, I. G. \& Rohman, A., 2007, Kimia Farmasi Analisis, 323-346, Pustaka Pelajar, Yogyakarta.

Hamdani, Syarif, dkk. (2012). Modul Praktikum Kimia Analisis. Bantung : Sekolah Tinggi Farmasi Indonesia.

Keenan, Charles W.1984.Kimia untuk Universitas .Jakarta : Erlangga

Mujamil, J.S. 1997. Deteksi dan EvaluasiKeberadaan Boraks pada beberapa jenis makanan di Kotamadya Palembang. Cermin Dunia Kedokteran. Vol 120 hal 17 $-20$

Pitojo, S, Zumiati. 2005. Cincau Cara Pembuatan dan Variasi Olahannya. PT Agromedia Pustaka, Tangerang.

Roth, H. J. 1988. Analisis Farmasi. Gadjah Mada University Press. Yogyakarta.

Vogel.(1979). Buku Teks Analisis Anorganik Kualitatif Makro dan Semimakro.Jakarta : PT Kalman Media Pustaka

Widyaningsih, T.W, dan E.S. Murtini, 2006. Alternatif Pengganti Formalin pada produk pangan. Trubus Agirasana, Surabaya.

Winarno, F.G. dan T.S.Rahayu, 1994.Bahan Makanan Tambahan untuk Makanan dan Kontaminan. Pustaka Sinar Harapan, Jakarta. 